\title{
Optimization of paddy nursery age for manual paddy transplanter (Hand cranking type)
}

C.R. KAVITKAR, V.V. AWARE, M.R. PATIL, P.U. SHAHARE, K.G. DHANDE, N.A. SHIRSAT AND S.V. AWARE

Received : 28.02.2017; Revised : 17.03.2017; Accepted : 25.03.2017

See end of the Paper for authors' affiliation

Correspondence to :

\section{C.R. KAVITKAR}

College of Agricultural Engineering and Technology, Dr. B.S.Konkan Krishi Vidyapeeth, Dapoli, RATNAGIRI (M.S.) INDIA

Email : chhayakavitkar77@ gmail.com
-ABSTRACT : This field experiment was conducted at Agronomy field, DBSKKV, Dapoli. Three different ages of nursery as 21, 28 and 35 DAS were taken for study. Plant and field parameters were measured during operation with manual paddy transplanter (hand cranked). The 21 (DAS) nursery required less time ( $25 \mathrm{~min}$ ) for uprooting and preparing root washed seedlings from area of $1 \mathrm{~m}^{2}$ as compared to that of for 28 (DAS) (35 min) and 35 (DAS) (42 min) nursery. Missing of hills were also less in 21 (DAS) nursery. The field capacity with existing manual paddy transplanter (hand cranking) was $0.020 \mathrm{ha} / \mathrm{h}$ for 21 (DAS) nursery, whereas, for 28 and 35(DAS) nursery it was found $0.018 \mathrm{ha} /$ $\mathrm{h}$ and $0.019 \mathrm{ha} / \mathrm{h}$, respectively. Hence, 21 (DAS) nursery was found suitable for manual paddy transplanter (hand cranking).

- KEY WORDS : Paddy transplanter, Hand cranking, Missing hills, Field capacity

- HOW TO CITE THIS PAPER : Kavitkar, C.R., Aware, V.V., Patil, M.R., Shahare, P.U., Dhande, K.G., Shirsat, N.A. and Aware, S.V. (2017). Optimization of paddy nursery age for manual paddy transplanter (Hand cranking type). Internat. J. Agric. Engg., 10(1) : 141-145, DOI: 10.15740/HAS/ IJAE/10.1/141-145. 